\title{
Company's strategic success as the basis of its potential sustainability
}

\author{
Oliver Orlov ${ }^{1}$, Kathrin Dumanska ${ }^{2, *}$, Nataliya Ponomaryova $^{3}$, and Dmytro Kobets ${ }^{3}$ \\ ${ }^{1}$ Khmelnytsky National University, Department of Marketing and Trade Entrepreneurship, 11 Instytutska Str., Khmelnytsky, 29000, \\ Ukraine \\ ${ }^{2}$ Khmelnytsky National University, Department of Enterprise Economics and Entrepreneurship, 11 Instytutska Str., Khmelnytsky, \\ 29000, Ukraine \\ ${ }^{3}$ Khmelnytsky National University, Department of Accountancy, Audit and Taxation, 11 Instytutska Str., Khmelnytsky, 29000, Ukraine
}

\begin{abstract}
The study of corporate sustainability is becoming more relevant in the world economy, thus the connection between global economic processes and political, environmental and society problems was revealed by authors. Given research is devoted to the analysis of the processes of sustainability of Ukrainian and foreign companies. The results of studies of scientific works and interviews with different countries businessmen showed that the sustainable development of the same company should be considered in several directions, namely, in economic, social and environmental. Supporting new institutional concept research that focuses on the sector problems of company's stability, we have compared theories of corporate sustainability and corporate social responsibility and highlighted the economic dimension as a basis of company's sustainable development. As a result of our research in economic directions of corporate sustainability the Methodology of evaluation of company's sustainability potential was proposed. The suggested methodology can ensure corporate sustainability for the strategic period. Proposed in the paper methodology assesses the strategic potential of company's success, its competitive status and capacity potential, and transform capabilities into competitive advantages. The implementation of the Methodology of evaluation of company's sustainability potential, according to authors view point, can be proposed as the basis of strategic management in forecasting and planning processes in industrial companies.
\end{abstract}

\section{Introduction}

During the period of development of "economic states" that are characterized as transnational and multinational corporations, as well as international economic-political alliances and international alliance networks, it becomes evident that active consolidation of different countries economies creates the basis for effective international cooperation. In its turn, the potential basis of international corporate cooperation of each country is the process of structural and economic consolidation of business entities and the creation of corporate associations. Thus, within individual economies it can be formed either cores of future transnational and multinational corporate entities, or the structural units of existing companies of domestic and/or international corporate business. The expansion of the corporate sector in certain branches of economies of the developed countries gives them the growth of GDP and export sales, but countries with weaker economic development obtain only opportunities to attract investments into the economy. It should be noted that the processes of creating global corporate systems are a manifestation of the consolidation of economic, labor, energy and other resources at the level of international economic and political cooperation, and thus form the basis of the world system of specialization and cooperation.

It was revealed that the key to the company's effective development is its financial and economic stability in the market. Corporate sustainability is especially important in the international markets operating under conditions of high volatility and emergence of competitive environment. Contemporary competitive markets require companies that respond quickly and flexibly to the challenges of the environment, and thus have high sensitivity to the actions of competitors, which can be transformed into partners. From the authors' point of view, the corporate sustainability is directly related to the concept of successful activity potential.

Our authors' group interprets the company's "strategic potential of success" as a set of available resources, opportunities and strengths, which in favorable market conditions for the company can be transformed into competitive advantages, increasing profitability and costeffectiveness. The authors' stress that it is precisely the high level of company's strategic potential of success is the basis of its sustainability. The global rankings of successful companies with constantly increasing revenues that ensure stability of their development and leading

\footnotetext{
* Corresponding author: KathrynD@bigmir.net
} 
positions in the ratings confirm author's position on the problem.

Analyzed public information confirms that the sustainability of modern companies is one of the top topics at international economic summits. During the work of New York Sustainability Summit (July 16-17, 2019) the opportunities to achieve success in tangibly improving environmental, governance and social (EGS) conditions were discussed. This Sustainability Summit has provided a unique opportunity for sustainability practices for leading companies to get specified knowledge how to be the best in the business and be able to generate EGS impact [1]. The main objective of the $3^{\text {rd }}$ Annual Strategic CSR \& Sustainability Summit (July 45,2019 ) in Mumbai was a decision making of creation an important tool for protecting and enhancing the goodwill, defending attacks and increasing competitiveness [2]. The participants of the $18^{\text {th }}$ annual Responsible Business Summit Europe, London (June 10-12, 2019) discussed problems of such global pressures on business as climate changes, investors, new consumer reactions, innovations etc. The RBS-2019 "has ambitious plans for 2020 with $750+$ of the world's leading CEOs, Heads of sustainability and investors convening in London 2020" [3].

\section{Literature review}

What is the concept of corporate sustainability? The views of companies and global organizations on this issue are somewhat different.

For the first time, the concept of sustainability was formulated by the Brundtland Commission in 1987, and later this term was used in the concept of sustainability at the 1992 UN Conference on the Environment in Rio de Janeiro [4]. The UN General Assembly defines the concept of corporate sustainability, the "global model of future civilization", as a development strategy that has emerged in response to the growing threat of an environmental crisis. This strategy combines three areas of company's activity: economic, social and environmental. Therefore, from the UN's point of view, the economic benefit of a company must take into account not only its profit but also the pressure on the environment [5]. In this situation, the global community perceives one of the main tasks of corporate business in reducing environmental risks by constructing or upgrading treatment plants, dramatically replacing the raw material base of production processes, and other technological changes that can protect the environment.

Company management perceives corporate stability as such, a source of profitability and efficiency, and thus considers the concept of "sustainability" in conjunction with "corporate social responsibility". Quite often, business representatives identify these definitions.

"In Unilever instead of social responsibility we prefer the term "corporate sustainability" as the strategy that underpins our business operations; ... when Paul Polman presented the Plan of Sustainability and Quality of Life to the world in 2010, it (we mean our corporate strategy) was fully revealed" in the form of "reducing the environmental impact, improving sanitation, creating opportunities for women ..." [6].

Reviewed results of McKinsey Company's research on corporate goals, incentives and motivation for corporate sustainability have shown that among "reasons for pursuing sustainability, from reputation management to operational improvements and new growth opportunities, the overall high degree of integration seems to indicate that companies have become more businesslike about their sustainability agenda. Most companies, however, are still struggling to factor sustainability into the "hard" areas of their business, such as supply chain and the budget, so there is still a lot of potential to drive further integration and increased value creation" [7].

Representatives of Ukrainian corporate business treat sustainability not only from the point of view of economic benefits, but also consider its impact on the environment, economy and society. Such companies as Deloitte, Mriya Farming PLC, JSC "Ukrainian Railways", consider upholding the interests of workers, their proper decent conditions, job creation, and openness of their own corporate policies for both clients and investors as the basis of their own sustainable development [8].

Thorough analysis of the literature on the problems of sustainable corporate development conducted by foreign scientists indicates, in its turn, the existence of supporters of different view points on the concept of corporate sustainability (CS): “... some articles identify CS with corporate environmental issues. ... some other studies used the term to refer to corporate social issues, which is, the social sustainability aspect of the firm. Finally, there are articles that take this approach and identify CSs with both social and environmental issues and how they relate to economic sustainability". [9]

Such authors as Montiel and Delgado-Ceballos conducted investigations on determining and evaluating the level of company's sustainable development on the basis of theories of stakeholder, institutional, resourcebased, corporate sustainability and subsequently concluded that companies need non-financial reporting that allows the public to get acquainted with the company's activities and evaluate it from the point of view of efficiency for customers and society. Such openness, in their opinion, also increases the interest of investors to companies [10]. Hussain, Rigoni \& Cavezzali investigated the relationship between sustainability performance (SP) and financial performance (FP) of company. As a result, a model of assessing the impact of sustainability performance (SP) on financial performance (FP) was proposed, such a model allows us to assess the financial value of the stability of a company's development [11]. Peculiarities of corporate reporting with the goal of creating a positive image of the company, the advantages of financial and non-financial reporting from the point of view of planning sales volumes are presented in the works of a group of Singaporean scientists [12].

Research in the field of investor attraction to the company, taking into consideration the stability of its development as a leading factor in investment attractiveness, is conducted by a group of scientists of Harvard Business School as Grewal, Serafeim and Yoon. "Managers may not act in the best interests of 
shareholders but rather respond to engagement on immaterial proposals in order to satisfy the sponsoring shareholders and protect their reputations" [13]. In terms of analyzing the impact of social responsibility on the investment attractiveness of the company, Ioannou I and Serafeim offer a model of assessing the level of the company's attractiveness for investors [14]. In their further researches, Serafeim and co-author Hawn reveal the dual nature of Corporate Social Responsibility (CSR), which perceive a significant difference between the company's internal need to increase production and the external need to adhere to socially necessary standards of output with regard to corporate responsibility [15].

Continuing their research, representatives of the London Business School and Harvard Business School, such as Ioannou and Serafeim, studied the strategic nature of corporate stability and proved that stability is one of the leading aspects of the company's long-term strategy necessary for practical implementation in company's activities [16]. In their scientific studies, Adams and Larrinaga explored the process of increasing the interest of companies in different countries in analyzing the causes of sustainability and studying the results of sustainable business development. The results of their research in the period from 2007 to 2017 showed not only the expansion and improvement of the methodological base of accounting and analysis of corporate sustainability, but also confirmed the fact that the study of corporate sustainability is one of the main goals of company's corporate strategy [17].

Considering the above scientific positions, we note that corporate sustainability is directly connected with questions of environmental protection. Moreover, with an account of the revenues entering of corporate business, the public consciousness of management should take into consideration the necessity of allocation certain share of profit to reduce the environmental risks from corporate activities. However, our authors' group is leaning toward the thought of those scholars who separate the positions of economic and social views on the corporate sustainability. From our point of view, the sustainability of one and the same company should be considered in different directions, such as economic, social and environmental. "... that organizations that voluntarily integrate environmental and social policies in their business model represent a fundamentally distinct type of the modern corporation, characterized by a governance structure that in addition to financial performance, accounts for the environmental and social impact of the company, a long-term approach towards maximizing inter-temporal profits, an active stakeholder management process, and more developed measurement and reporting systems" [18]. It is the consideration of corporate sustainability in the economic direction that is suggested in our studies.

Generally speaking, the proposed research is now in the process of being tested and practical results are not yet confirmed. But our author group continues our research in the area of accumulating of company's potential success, increasing competitive status and ensuring corporate sustainability.

\section{Methodology of researching}

The authors of the report have appraised the Methodology of evaluation of company's sustainability potential, that allow them to assess the strategic potential of company's success, competitive status and ability potential for strategic development of the company. The Methodology of evaluation of company's sustainability potential can become the basis for strategic forecasting and planning in industrial companies.

Methodology of evaluation of company's sustainability potential includes the group of methods that can be consistently applied in industrial companies' strategy of sustainability:

1. Method of assessing the strategic potential of company's success.

2. Method of estimating the company's competitive status.

\section{Results}

\subsection{Method of assessing the strategic potential of company's success}

According to authors' point of view, the possibilities of using one's potential depend on the competencies and resources of the company. The complexity of the problem determines the necessity for a balanced distribution of tasks within the strategic management of potential of success. The essence of the matter is to identify market potential using strategic means of "early detection", which include methods for assessing company's resource potential. The first and the most important of the proposed methods is the Method of assessing the strategic potential of company's success.

Conducting research in corporate sustainability area we concluded that magnitude of the strategic potential of company's success is characterized by the level of strategic reserve, which is necessary for its successful sustainability. By "successful sustainability" we mean only the break-even activity but not profitable one, because in the Ukrainian economy the break-even tendency for the most companies can be described as a prospect of stability and success.

Method of assessing the strategic potential of company's success, which is based on determining the ratio of potential capacity estimation (RPCE). The ratio of potential capacity estimation is calculated by dividing the value of existing capacity potential (ECP) into the value of required (planned or necessary) capacity potential (RCP) in scoring system, and these values are estimated on a scale from 1 to 10 . Consequently, the potential of success is determined by dividing the total ratio of potential capacity estimation (according to estimation parameters) by the sum of evaluation parameters.

In order to calculate the strategic potential of company's success, our author team proposed formula (1).

SPS $_{\text {comp. }}=(R P C E \times(P C P+D S A+P L S B U)) / 100(1)$ 
where $R P C E$ - ratio of potential capacity estimation, $P C P$ - prospective capacity potential, DSA - degree of strategic adaptation of company with the optimal strategy, $P L S B U$ - perspective level of strategic business units.

Authors propose to take the optimal value of the strategic potential of company's success for $100 \%$, as a priori under normal conditions the company has a $100 \%$ success rate of activity due to the existing corporate strategy. Therefore, in order to determine the magnitude of the strategic potential of company's success in the given conditions, it is necessary to compare this value with the optimal value, that is, to divide by $100 \%$. Then the magnitude of the strategic potential of company's success can be characterized on the following scale:

- from $33.5 \%$ - low SPS,

- from $33.5 \%$ to $70 \%$ - average SPS,

- from 70\% - high SPS.

The benchmark of the proposed method, the ratio of potential capacity estimation ( $R P C E$ ) allows establishing proportional relationship between the value of the existing capacity potential (ECP) and the value of the required capacity potential ( $R C P$ ) of the company to ensure its future sustainability. It should be noted that the abovementioned ratio of potential capacity estimation (RPCE) actually makes it possible to determine the average value of company's capacity at a given time, taking into consideration its existing and required values. Thus, the ratio of potential capacity estimation (RPCE) is firstly calculated according to each internal factor of potential capacity of functional units of company with the subsequent determination of their sum, and then for the company as a whole.

In order to calculate the ratio of potential capacity estimation of the company by the factors of potential capacity it is necessary to carry out formula (2).

$$
\mathrm{RPCE}=\frac{E C P_{\text {iex.fact }}}{R C P_{\text {ireq.fact }}}
$$

where $E C P_{\text {iex.fact }}-$ existing capacity potential of $i$-th factor, $R C P_{\text {ireq.fact }}$ - required capacity potential of $i$-th factor.

Such indicators as the level of the existing capacity potential of company and the level of the ratio of potential capacity estimation for each functional unit we determine according to scale of 1 to 10 . We suggest ranking the levels obtained at low, average and high levels according to the proportional distribution of their importance within the above scale, the range of which covers $100 \%$ assessment the internal capacity potential (ICP) of company's functional units and of company as a whole.

- from 1 to 3.5 - low level of ICP,

- from 3.5 to 7 - average level of ICP,

- from 7 to 10 - high level of ICP.

Out authors group proposes to calculate the magnitude of the prospective capacity potential (PCP) of company by the formula (3).

$$
\mathrm{PCP}=\frac{L P F C P}{\sum P F C P}
$$

where $L P F C P$ - strategic level of prospective factors of capacity potential, $\sum P F C P$ - sum of perspective factors of capacity potential.

As in similar cases, the optimal value of the indicator of the prospective capacity potential of company is taken as $100 \%$ or 1 , since a priori under normal conditions the company owns and plans to own in the future $100 \%$, that is, the overall potential of capacities and therefore the obtained value of the specified value must be compared with 1 or $100 \%$.

Results of our studies confirm that magnitude of the strategic adaptation of company (SAC) makes it possible to determine how effective its current strategy is in the current economic conditions. We propose to study the degree of strategic adaptation by identifying the success factor of active strategy in future (future success factor, $F S F$ ) and current success factors of active strategy (current success factors, CSF) and evaluate them on a scale from 0 to 1 , and then summarize the obtained results. Sums of values of current and future success factors of the current strategy are taken, respectively, as the levels of current strategy in the present and future. From the sum of success factors we propose to formulate variants of optimal corporate strategies, which in formula (4) are compared with the level of success of the current strategy. It should be noted that success factors are evaluated not accidentally, because success factors characterize future efficiency and are necessary for company's successful performance on the market. Success factor creates little or no negative impact, since it can be considered as the key to the continued corporative sustainability in emergent environment. Thus, the degree of strategic adaptation $(D S A)$ of company according to each variant of the optimal strategy is calculated according to formula (4).

$$
\mathrm{DSA}_{i}=\frac{\sum \mathrm{OS}_{j}}{\sum \mathrm{CFS}}
$$

where $\mathrm{DSA}_{i}$ - degree of strategic adaptation, where $i=1$, $2,3, \ldots, n, \sum \mathrm{OS}_{j}-$ level of alternative options of optimal strategy, where $j=1,2,3, \ldots, n ; C F S$ - level of current strategy factors.

The level of company's strategic adaptation is determined by comparing the degree of its strategic adaptation with the maximum possible amount of strategic adaptation, which we take for 10 , because success factors as dimensions of strategy are rated on a scale from 1 to 10 . Thus, the magnitude of the level of strategic adaptation of an industrial company we suggest to rank at low, average and high levels according to the proportional distribution of their importance within following scale, the range of which covers $100 \%$ assessment of strategic adaptation:

- from 1 to 3.5 - low level of DSA,

- from 3.5 to 7 - the average level of DSA,

- from 7 to 10 - high level of DSA.

The indicator of the perspective level of strategic business units (PLSBU) characterizes the degree of effective using of given $S B U$ as one of the market sectors within company's strategic business-unit's set. We propose to calculate the overall level of perspective of each $S B U$ according to formula (5).

$$
P L S B U=O S F_{s b u_{n}}+C T C_{s b u_{n}}+T L F A_{s b u_{n}}
$$


where $O S F_{S b u_{n}}$ - overall strategic flexibility of SBU, $C T C_{s b u_{n}}$ - current total contribution of this SBU to overall synergism level of company's SBU, TLF $A_{s b u_{n}}$ - total level of future attractiveness of SBU.

It is generally known that the process of a company's strategic business-unit's set formation is carried out on the basis of the results of each individual SBU research. In accordance with the magnitude of the overall level of prospects of each SBU, the most promising of them are chosen for further company's strategic business-unit's set formation. The total level of prospects for company's strategic business-unit's set is calculated by summing the values of the overall level of prospects of those SBU that were part of it.

In other words, the strategic potential of company's success is a proportional combination of the potential of its internal capacities with the potential of its market opportunities, which provide the company with the efficiency of applying the corporate strategy in conditions of its economic environment. Accumulation of strategic potential of success is carried out by accumulation of potential of internal capabilities considering company's market capabilities and the level of its strategic adaptation on the market.

In accordance with authors' opinion, evaluation of the strategic potential of company's success involves a total assessment of its internal capabilities, characterized by the level of its strategic adaptation and the level of prospects of company's strategic business-unit's set, which are adjusted by the ratio of potential capacity estimation of company as a whole.

\subsection{Method of estimating the company's competitive status}

It is necessary to underline that the method of estimating competitive status reflects company's competitive position in the market. The mathematically company's competitive status is the product of such values as the required level of investment (the current level - to determine the current competitive status, the planned one - to determine the future competitive -status), and the value of capacity standard, and the value of potential of success.

Evaluation of the company's competitive status is based on the strategic potential of success and the value of the current volume of real investment; the data are taken from the company's financial statements. The magnitude of a company's strategic success characterizes the overall level of its strategic capacities that is necessary to achieve break-even activity. The value of current volume of real investments characterizes the level of company's financing of current and non-current assets in order to expand its market capacities and increase its competitiveness.

We propose to calculate the magnitude of company's competitive status by the formula (6).

$$
C S_{\text {comp. }}=S P S_{\text {comp. }} \times V_{\text {rinv. }}
$$

where $S P S_{\text {comp. }}, \%$ - company's strategic potential of

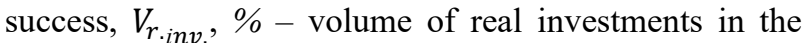
current period, which is expressed as a percentage of the maximum amount of company's real investments.

The optimal value of company's competitive status is $100 \%$, since a priori under normal conditions the company has a $100 \%$ level of competitiveness on the market. Therefore, in order to determine the magnitude of company's competitive status under the given conditions, it is necessary to compare this value with the optimal value, i.e. to divide by $100 \%$. Then the magnitude of company's competitive status can be characterized according to the following scale:

- from to $33.5 \%$ - low CS,

- from $33.5 \%$ to $70 \%$ - average CS,

- from $70 \%$ - high CS.

According to our beliefs, one of the most important strategic goals of a company that hopes to succeed is the transformation of market-relevant competencies into market competitive advantages. As a result of this process, the company is able to accumulate strategic success factors that shape the company's sustainable competitive status. Thus, transformation of the strategic potential of success and of the company's management, because such transformation aspects of competitive status into factors of success is the task is one of the leading strategic goals of the company, i.e. basic formation of company's sustainability.

\section{Conclusions}

Research of corporate sustainability provides for the account of emergence and volatility of unpredictable environmental factors. However, the reactive emergence of the company itself is able to overcome the possible negative effects of market volatility, since the emergent reactions of the company are manifested in the form of mobilization of fundamentally new strategic resources and opportunities to operate under uncertainty. Each company should include the results of forecasting a certain set of standard and non-standard emergent environmental challenges in the corporate strategy development process. Accordingly, in period of economic crisis and pre-crisis periods, the effective company's managers initiate the launch of a prearranged set of emergent reactions to unexpected "external challenges" [19].

The practical activity of successful foreign engineering companies such as the American corporations Ford Motors, General Motors, European concern PSA (France), Volvo (Sweden), Volkswagen (Germany) and international alliances such as Renault-Nissan-Mitsubishi (France-Japan) can hold the leading strategic positions in the volatile, highly competitive global automobile market, thanks to sometimes non-standard strategic decisions and, at the same time, flexible corporate strategies.

In particular, we consider the decision to create an operating board of the Renault-Nissan-Mitsubishi Machine-Building Alliance, as successful example strategic sustainability, which can completely control the alliance's activities, that "will be a major factor in the Alliance's "new start" and facilitate operational 
cooperation between companies and at the same time can help in finding new ways to make profit for their shareholders and employees" [20].

According to author's point of view, the strategic leaders of the global automobile industry provide advantageous strategic positions on the basis of corporate sustainability approach, i.e. the effective usage of strategic potential of success to solve economic problems, the principal of which are increasing of profitability and strengthening of market position.

Thereby, the key aspect of strategize company's sustainability management is considered by the authors to be the transformation of the strategic potential of success and aspects of competitive status into factors of success it is necessary to take into consideration all the peculiarities of environment emergent influence on of company's activity. Thus, company's sustainability management methods, including the level of its strategic potential of success, should take into consideration the limitations of company's influence on market potential.

It is necessary to remember that any organization is located and functioning under the influence of emergent environment, therefore, every action of all organizations without exception is possible only if the environment permits its existence. That is why the main task of the business entity when choosing the methods of managing the strategic potential of success is the thorough strategic analysis of the market environment in particular, macroenvironment, direct environment and the internal environment. In this case, it should be underlined three main systems necessary to solve company's sustainability tasks connected with accumulation of potential of success. Such systems include: strategic planning, implementation and control. These systems are respectively responsible for the development, implementation and revision of current strategy; complex application of the systems in the process of company's sustainability management provides the development of its successful strategy in future.

In this account we'd like to note, that the researches of our group in the field of company's potential sustainability are in the development process. The next stage will be its practical penetration into company's activity and several regional business entities have already confirmed their participation in mutual investigations. We suppose that manufactured application of proposed Methodology of evaluation of company's sustainability potential would assist the company's successful division.

\section{References}

1. Sustainability Summit. Haw Corporate Superstars Generate Impact, in Abstracts of Sustainability Summit, The Conference board, New York, NY, 1617 July 2019

2. Business Summit Europe, in Abstracts of the $18^{\text {th }}$ Responsible Business Summit Europe-2019, Ethical Corporation, London, UK, 10-12 June 2019
3. Sustainability Summit, in Abstracts of the $3^{\text {rd }}$ Annual Strategic CSR \& Sustainability Summit. The Conference board, Mumbai, India, 16-17 July 2019

4. A.D. Moiseev, I.F. Narizhny, Sushchnost ustoychivogo razvitiya economicheskikh system (The essence of sustainable development of economic systems). (2019)

5. Report of the World Commission on the Environment, in Abstracts of the United Nations General Assembly, Brundtland Commission, USA, Apr 1987

6. I. Antoshina, Strategiya ustoychivogo razvitiya. Kak vnedrit strategiyu KSO: mneniya professionalov (Sustainable development strategy. How to implement CSR strategy: opinions of professionals). (Sustainable business, 2019)

7. The business of sustainability. McKinsey \& Company sustainability (2011), https://www.mckinsey.com. Accessed 21 Oct 2011

8. T. Saharchuk, O. Chernigevich, N. Shmydyk, \& R. Kurinko, Chto takoe ustoiychivoe razvitie i pochemu ono aktualno dlya ukrainskogo biznesa (What is "sustainability" and why it is actually for Ukrainian business). (Sustainable business, 2019)

9. R.M.N.C. Swarnapali, Corporate sustainability: A Literature review. Journal for Accounting Researchers and Educators 1(1), 1-16 (2017)

10. I. Montiel, J. Delgado-Ceballos, Defining and Measuring Corporate Sustainability: Are We There Yet? Organization \& Environment 27(2), 113-139 (2014). doi:10.1177/1086026614526413

11. N. Hussain, U. Rigoni, E. Cavezzali, Does it pay to be sustainable? Looking inside the black box of the relationship between sustainability performance and financial performance. Corporate Social Responsibility and Environmental Management 25(6), 1198-1211 (2018). doi:10.1002/csr.1631

12. L. Loh, T. Thomas, Y. Wang, Sustainability reporting and firm value: evidence from Singapore-listed companies. Sustainability 9, 2112 (2017)

13. J. Grewal, G. Serafeim, A. Yoon, Shareholder activism on sustainability issues (Harvard Business School Working Paper, 2016), http://nrs.harvard.edu. Accessed 7 Jul 2016

14. I. Ioannou, G. Serafeim, The impact of corporate social responsibility on investment recommendations: Analysts' Perceptions and Shifting Institutional Logics. Strategic Management Journal 36(7), 1053-1081 (2015)

15. O. Hawn, G. Serafeim, Mind the gap: the interplay between internal and external actions in the case of corporate social responsibility, Strategic Management Journal 37(13), 2569-2588 (2016)

16. I. Ioannou, G. Serafeim, Corporate sustainability: a strategy? (Harvard Business School working paper, 2019)

17. C.D. Adams, C. Larrinaga, Progress: engaging with organisations in pursuit of improved sustainability 
accounting and performance. Accounting, Auditing and Accountability Journal 32 (2019). doi:10.1108/AAAJ-03-2018-3399

18. R. Eccles, I. Ioannou, \& Serafeim, The Impact of corporate sustainability on organizational processes and performance. Management Science 60(11), 2835-2857 (2014). doi:10.1287/mnsc.2014.1984

19. M. Voynarenko, K. Dumanska, N. Ponomaryova, Formation of company's economic activity context in the strategic positioning process in emergent environment conditions. SHS Web of Conferences 65, 04005 (2019). doi:10.1051/shsconf/20196504005

20. K.S. Dumanska, Stratehizatsiia mashynobudivnykh kompanii Ukrainy $\mathrm{v}$ umovakh volatylnosti avtomobilnoho rynku (Strategization of Ukrainian machine building companies in conditions of automobile market's volatility), in International Forum "New Economics-2019", Kyiv, November 2019, vol. 2 (Spacetime, Kyiv, 2019), pp. 81-86 